\title{
Economic Dispatch Analysis Using Equal Incremental Cost Method with Linear Regression Approach
}

\author{
Arnawan Hasibuan ${ }^{\bowtie}, 2$, Robi Kurniawan ${ }^{3}$, Muzamir Isa ${ }^{4}$, Mursalin ${ }^{5}$ \\ 1Department of Electrical Engineering, Universitas Malikussaleh, Bukit Indah, Lhokseumawe, Indonesia, \\ arnawan@unimal.ac.id

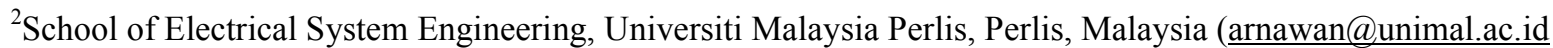 \\ ${ }^{3}$ Department of Electrical Engineering, Universitas Malikussaleh, Bukit Indah, Lhokseumawe, Indonesia, \\ robikurniawan467@gmail.com \\ ${ }^{4}$ School of Electrical System Engineering, Universiti Malaysia Perlis, Perlis, Malaysia \\ muzamir@unimap.edu.my \\ ${ }^{5}$ Department of Mathematics, Universitas Malikussaleh, Aceh Utara, Indonesia, mursalin@unimal.ac.id \\ ${ }^{\bowtie}$ Corresponding author : arnawan@unimal.ac.id
}

\begin{abstract}
Received : February 7, 2021
Revision : February 16, 2021

Accepted : March 5, 2021

Abstract

The use of fuel is one thing that needs special attention, because most of the operating costs of a plant are fuel costs.One of the efforts to minimize the cost of generating fuel is called Economic dispatch.In this study, an Equal Incremental Cost method with a Linear Regression approach will be presented to obtain a minimum generation cost.The case taken is the Pangkalan Susu PLTU which operates two generating units. Based on the results of calculations using the Equal Incremental Cost method with the Linear Regression approach, the cost is $-0.033 \%$ or an average of $-13,111 \$ /$ hour.
\end{abstract}

Keywords : Economic Dispatch; Equal Incremental Cost Method; Linier Regression

\section{Introduction}

The use of fuel is one of the things that needs special attention in the operation of power plants, because about $60 \%$ of the total operational costs incurred are fuel costs (Marsudi, 2006). Changes in the demand for electrical energy on the load side will cause fluctuations in fuel costs. These fluctuations are very difficult to predict and are always changing, therefore we need a very fast system to cope with and respond to them (Syah et al., 2012). The analysis to produce the minimum cost at the generator is usually referred to as economic dispatch. Economic Dispatch is the distribution of loading on generating units in the system optimally and economically at a certain system load price. With the application of economic dispatch to the electricity generating unit, the minimum generation cost for electricity production will be obtained (Syah et al., 2012)(Pramudia, Hardiansyah and Junaidi, no date).

There are two methods of approach taken to solve the economic dispatch problem, namely the numerical method and the meta-heuristic method (Takeang and Aurasopon, 2019). Examples of numerical method solutions in economic dispatch problems include using the Lagrange method (Syah et al., 2012), Lambda Iteration (Dike, Adinfono and Ogu, 2013), Dynamic Programming Techniques (Nabila, 2017), Equal Incremental Cost (Hasibuan, no date) while the metaheuristic method solution, for example using the Particle Swarm Optimization method (Dewangan, Jain and Huddar, 2015), Cuckoo Optimization Algorithm (Iskandar, 2016), Artificial Bee Colony Algorithm (Pramudia, Hardiansyah and Junaidi, no date), Taguchi (Rusilawati, Penangsang and Soeprijanto, no date). Previous research conducted by Arnawan Hasibuan examined the Economical Operation of a Steam Power Plant Using the Equal Incremental Cost Method with a Linear Regression (Least Square) Approach, obtained savings are when compared with an even distribution of the total power output to the generating units (Hasibuan, no date). This research was conducted using the Equal Incremental Cost method with the Linear Regression (Least Square) approach to obtain the minimum power plant operating costs. The calculation of the Equal Incremental Cost method to calculate economic dispatch is carried out by using constrain equality and inequality constrain (Syah et al., 2012). Equality constraint is a power balance limitation, which requires that the total power generated by each generator must be equal to the total required load and transmission losses(Syah et al., 2012)(Nabila, 2017).Inequality constraint is a cost function that is not influenced by reactive power but on the real power balance in the system(Suman et al., 2016).

\section{Literature Review}

\section{Electric Power System operation}

Operation of the power system is an operating process to produce electric power from a generation, transmission distribution, distribution to consumer loads. The main objective of operating the electric power system is to meet needs 
efficiently, namely to meet the load at an optimal and economical cost by paying attention to reliability that meets environmental safety standards and can serve demand continuously from time to time(Pertiwi, Syahrizal and Siregar, 2018). The operation of the electric power system at a fixed frequency is said to be in a balanced power state if the total real power generated is equal to the total system load. In the form of an equation written as follows (Kristianto, Suyono and Wijono, 2014).

$$
\begin{aligned}
& P_{G}=P_{R}+P_{L} \\
& P_{G}=\sum_{i=1}^{n} P_{i}
\end{aligned}
$$

Where:

$$
\begin{aligned}
& P_{G}=\text { The total power generated by the generator (MW) } \\
& P_{R}=\text { total system load (MW) } \\
& P_{L}=\text { Total loss - actual loss of power from the transmission line (MW) } \\
& P_{i}=\text { The power generated by the ith generator (MW) } \\
& n=\text { Number of generators in the system }
\end{aligned}
$$

\section{Power Plant Economical Operation Considerations}

Economic operation is the process of dividing or rationing the total load for each generating unit, all generating units are controlled continuously at certain time intervals so that optimal operation is achieved, so that the generator can be run in the most economical manner (Hakimah, 2016). The considerations taken to achieve the economic operation of the power system can be divided into two parts, namely the economic dispatch and the unit commitment (Mariang, no date).

\section{Economic Dispatch}

Economic Dispatch is a method used to divide the power generated by the generating unit to meet load requirements. This power plant aims to get the cheapest generation costs (Nabila, 2017). In the Economic Dispatch, there are two certain constraints that must be met, namely the Equality constraint and the Inequality constraint (Syah et al., 2012)(Suman et al., 2016). Equality constraint can be expressed by equations 1 and 2.The inequality constraint is stated in the following equation:

$$
P_{i, \min } \leq P \leq P_{i, \max }
$$

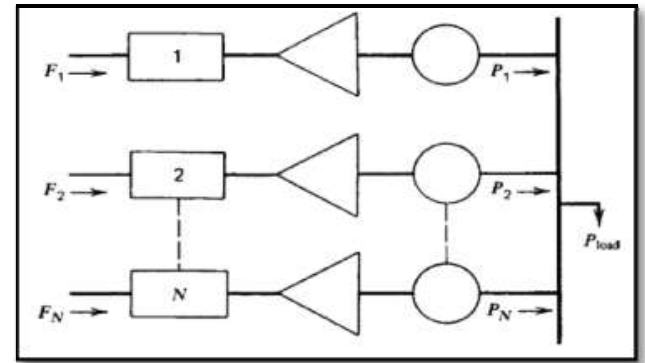

Figure 1. $\mathrm{N}_{\text {gen }}$ thermal units committed to serve a load of $P_{\text {load }}$ (Wood and Wollenberg, 1996)

Figure 1 shows the configuration of multiple load serving generators. This system consists of $\mathrm{N}$ thermal generator

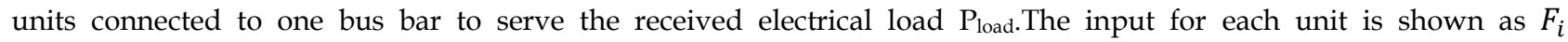
representing the cost of fuel from the units whose total quantity is :

$$
\begin{aligned}
& F_{\text {total }}=F_{1}+F_{2}+F_{3}+\ldots+F_{N}=\sum_{i=1}^{N} F_{i}\left(P_{i}\right) \\
& P_{\text {total }}=P_{1}+P_{2}+P_{3}+\ldots+P_{N}=\sum_{i=1}^{N} F_{i}\left(P_{i}\right) \\
& \emptyset=0=P_{\text {load }}-\sum_{i=1}^{N} P_{i}
\end{aligned}
$$

\section{Generator Input-Output Characteristics}

Each generator has its own characteristics in operation. The input-output characteristics of a thermal generator are characteristics that describe the relationship between the input in the form of heat energy demand (MBtu/hour) or fuel (liters/hour) and the output produced by the generator (MW)(Pertiwi, Syahrizal and Siregar, 2018)(Syafii and Monice, no date).

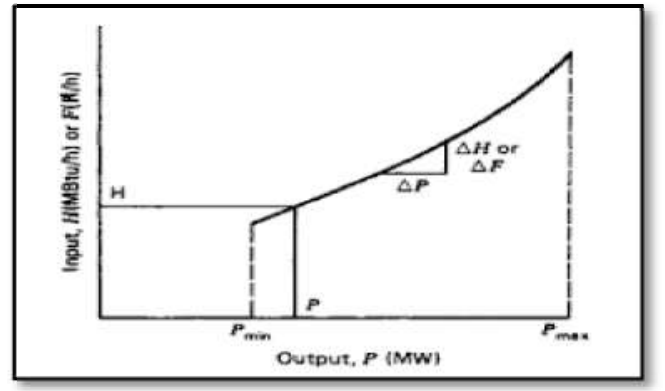

Figure 2. Characteristic curves of the generator input-output 


\section{Linear Regression (Least Square)}

The linear regression equation is an equation model describes the relationship between one independent variable/predictor $(\mathrm{X})$ and one non variable free/response $(\mathrm{Y})$, which is usually represented by a straight line. Below is a straight line equation namely (Yuliara, 2016).

$\lambda=a P+b$

The magnitude of the constants a and $\mathrm{b}$ can be determined using equations:

$$
\begin{aligned}
& a=\frac{\mathrm{n} \sum(\mathrm{PF})-\sum \mathrm{P} \sum \mathrm{F}}{\mathrm{n} \sum \mathrm{P}^{2}-\left(\sum \mathrm{P}\right)^{2}} \\
& b=\frac{\left(\sum \mathrm{P}\right)^{2} \cdot \sum(\mathrm{F})-\sum P \cdot \sum(\mathrm{PF})}{\sum \mathrm{P}^{2} \cdot \mathrm{n}-\left(\sum \mathrm{P}\right)^{2}}
\end{aligned}
$$

The above formula can be converted into a $2 \times 2$ matrix as below:

$$
\left[\begin{array}{cc}
N & \sum P_{i} \\
\sum P_{i} & \sum P_{i}^{2}
\end{array}\right]\left[\begin{array}{l}
a \\
b
\end{array}\right]=\left[\begin{array}{c}
\sum F_{i} \\
\sum P_{i} F_{i}
\end{array}\right]
$$

Where:

$$
\begin{aligned}
& F=\text { Put in fuel }(\$ / \mathrm{h}) \\
& P=\text { Power output }(\mathrm{MW}) \\
& a, b=\text { linear line constants } \\
& \mathrm{n} \quad=\text { The amount of data }
\end{aligned}
$$

\section{Equal Incremental Cost Method}

The unit cost of additional fuel (Equal Incremental Cost) of a unit for each output is the limit on the ratio of the increase in fuel input cost in dollars per hour to the corresponding increase in power output in MW as the increase in power output approaches zero. Mathematically, Equal Incremental Cost can be calculated using the following equation:

$$
\text { EqualincrementalCost }=\frac{\mathrm{dF}_{\mathrm{i}}}{\mathrm{dP}_{\mathrm{i}}}
$$
Where:

$$
\begin{aligned}
& F_{i}=\text { Input to unit } \mathrm{i}(\$ / \mathrm{h}) \\
& P_{i}=\text { Unit output } \mathrm{i}(\mathrm{MW})
\end{aligned}
$$

\section{Research Methods}

The stages carried out in this research are literature study or literature review, study guidance, data collection and processing, and calculation simulation with Matlab and Microsoft Excel. Below is a picture of a flow chart for calculating the Equal Incremental Cost method with the Linear Regression approach to obtain the minimum generation cost.
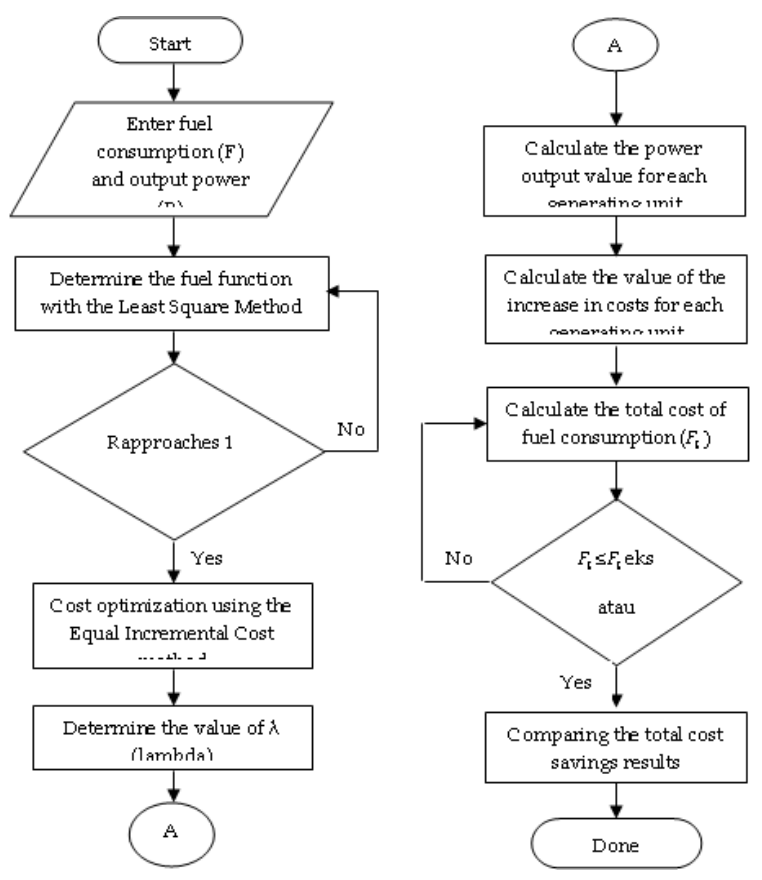

Figure 3. Flowchart of Calculation of the Equal Incremental Cost Method 


\section{Results and Discussion}

\section{Operational Data of Pangkalan Susu PLTU}

Table 1. Unit Calculation Data 1

\begin{tabular}{|c|c|c|c|}
\hline Power (MW) & Fuel Flow (ton/hour) & Cost (Rp) & Cost $(\$)$ \\
\hline 45.00 & 39.10 & $42,658,100$ & $3,047.01$ \\
\hline 70.70 & 49.80 & $54,331,800$ & $3,880.84$ \\
\hline 91.50 & 64.70 & $70,587,700$ & $5,041.98$ \\
\hline 134.00 & 77.00 & $84,007,000$ & $6,000.50$ \\
\hline 116.90 & 86.80 & $94,698,800$ & $6,764.20$ \\
\hline \multicolumn{4}{|c|}{ Table 2.Unit Calculation Data 2} \\
\hline Power (MW) & Fuel Flow (ton/hour) & Cost (Rp) & Cost $(\$)$ \\
\hline 45.20 & 40.70 & $44,403,700$ & $3,171.69$ \\
\hline 63.90 & 45.20 & $49,313,200$ & $3,522.37$ \\
\hline 91.80 & 62.70 & $68,405,700$ & $4,886.12$ \\
\hline 124.00 & 80.00 & $87,280,000$ & $6,234.29$ \\
\hline 165.00 & 100.00 & $109,100,000$ & $7,792.86$ \\
\hline
\end{tabular}

Table 3. Electricity load data for the Pangkalan Susu PLTU

\begin{tabular}{cccc}
\hline Hour & Unit 1 & Unit 2 & Cost $(\$ / \mathrm{h})$ \\
\hline $00: 00$ & 126 & 151 & $13,676.616$ \\
$01: 00$ & 127 & 142 & $13,348.237$ \\
$02: 00$ & 127 & 140 & $13,265.617$ \\
$03: 00$ & 127 & 147 & $13,555.347$ \\
$04: 00$ & 127 & 150 & $13,679.997$ \\
$05: 00$ & 127 & 149 & $13,638.415$ \\
$06: 00$ & 128 & 148 & $13,641.928$ \\
$07: 00$ & 129 & 146 & $13,604.055$ \\
$08: 00$ & 129 & 148 & $13,687.059$ \\
$09: 00$ & 130 & 148 & $13,732.258$ \\
$10: 00$ & 116 & 148 & $13,105.660$ \\
$11: 00$ & 127 & 147 & $13,555.347$ \\
$12: 00$ & 121 & 146 & $13,244.911$ \\
$13: 00$ & 122 & 144 & $13,206.690$ \\
$14: 00$ & 119 & 146 & $13,155.805$ \\
$15: 00$ & 117 & 146 & $13,066.971$ \\
$16: 00$ & 123 & 147 & $13,375.775$ \\
$17: 00$ & 124 & 148 & $13,462.084$ \\
$18: 00$ & 124 & 146 & $13,379.080$ \\
$19: 00$ & 123 & 146 & $13,334.289$ \\
$20: 00$ & 120 & 145 & $13,158.870$ \\
$21: 00$ & 120 & 144 & $13,117.448$ \\
$22: 00$ & 120 & 145 & $13,158.870$ \\
$23: 00$ & 122 & 147 & $13,331.052$ \\
\hline
\end{tabular}

\section{Modeling Generating Units with Linear Regression (Least Square)}

This generating unit modeling aims to determine the input-output characteristic equation of a generating unit. Calculate the equation of the input-output characteristics of each generating unit with simulation matlab. The equation of the input-output characteristics of the unit one generator is obtained.

$\frac{d F_{1}}{d P_{1}}=42.5 P_{1}+1,052.1$

And the equation for the input-output characteristic of the unit two generator is:

$\frac{d F_{2}}{d P_{2}}=40.1 P_{2}+1,194.9$

Optimization Using Equal Incremental Cost Method

Optimization of costs when the load is $277 \mathrm{MW}$

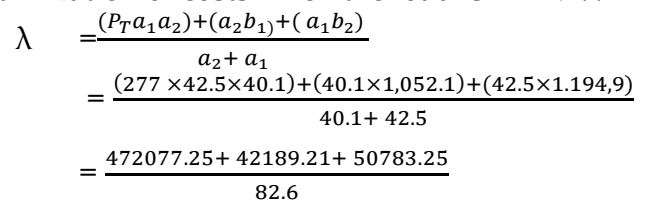




$$
=6,840.795
$$

The power in each generating unit is:

$$
\begin{aligned}
\mathrm{P}_{1} & =\frac{\lambda-b_{1}}{a_{1}} \\
& =\frac{6847095-1,05.2}{425} \\
& =136.205 \mathrm{MW} \\
\mathrm{P}_{2} & =\frac{\lambda-b_{2}}{a_{2}} \\
& =\frac{6847095-1194.9}{401} \\
& =140.795 \mathrm{MW}
\end{aligned}
$$

Obtained per unit cost viz:

$$
\begin{aligned}
F_{1} & =a_{1} P_{1}+b_{1} \\
& =42.5(136.205)+1,052.1 \\
& =\$ 6,840.812 \\
F_{2} & =a_{2} P_{2}+b_{2} \\
& =40.1(140.795)+1,194.9 \\
& =\$ 6,840.779 \\
F_{t}= & F_{1}+F_{2}=6,840.812+6,840.779=\$ 13,681.591
\end{aligned}
$$

For the next load optimization is done with the same calculation. The results of optimization calculations using the Equal Incremental Cost method using the Linear Regression approach can be seen in Table 4.

Table 4.Optimization Results with Equal Incremental Cost Method

\begin{tabular}{ccccc}
\hline Hour & $\mathrm{P}_{1}(\mathrm{MW})$ & $\mathrm{P}_{2}(\mathrm{MW})$ & $\mathrm{P}_{\mathrm{T}}=\mathrm{P}_{1}+\mathrm{P}_{2}$ & Cost $(\$ / \mathrm{h})$ \\
\hline $00: 00$ & 136.205 & 140.795 & 277 & $13,681.591$ \\
$01: 00$ & 132.321 & 136.679 & 269 & $13,351.469$ \\
$02: 00$ & 131.350 & 135.650 & 267 & $13,268.94$ \\
$03: 00$ & 134.749 & 139.251 & 274 & $13,557.797$ \\
$04: 00$ & 136.205 & 140.795 & 277 & $13,681.591$ \\
$05: 00$ & 135.720 & 140.280 & 276 & $13,640.328$ \\
$06: 00$ & 135.720 & 140.280 & 276 & $13,640.328$ \\
$07: 00$ & 135.234 & 139.766 & 275 & $13,599.061$ \\
$08: 00$ & 136.205 & 140.795 & 277 & $13,681.591$ \\
$09: 00$ & 136.691 & 141.309 & 278 & $13,722.857$ \\
$10: 00$ & 129.894 & 134.106 & 264 & $13,145.145$ \\
$11: 00$ & 134.749 & 139.251 & 274 & $13,557.797$ \\
$12: 00$ & 131.350 & 135.650 & 267 & $13,268.94$ \\
$13: 00$ & 130.865 & 135.135 & 266 & $13,227.675$ \\
$14: 00$ & 130.379 & 134.621 & 265 & $13,186.409$ \\
$15: 00$ & 129.408 & 133,592 & 263 & $13,103.879$ \\
$16: 00$ & 132.807 & 137.193 & 270 & $13,392.736$ \\
$17: 00$ & 133.778 & 138.222 & 272 & $13,475.267$ \\
$18: 00$ & 132.807 & 137.193 & 270 & $13,392.736$ \\
$19: 00$ & 132.321 & 136.679 & 269 & $13,351.469$ \\
$20: 00$ & 130.379 & 134.621 & 265 & $13,186.409$ \\
$21: 00$ & 129.894 & 134.106 & 264 & $13,145.145$ \\
$22: 00$ & 130.379 & 134.621 & 265 & $13,186.409$ \\
$23: 00$ & 132.321 & 136.679 & 269 & $13,351.469$ \\
\hline
\end{tabular}

\section{Comparison of Optimization Results and Discussion}

Table 5. Comparison of the cost of optimization results between the Equal Incremental Cost method and the actual costs in the field

\begin{tabular}{ccccc}
\hline Hour & $\mathrm{P}_{\mathrm{T}}=\mathrm{P}_{1}+\mathrm{P}_{2}$ & True Cost $(\$ / \mathrm{h})$ & IEC Method $(\$ / \mathrm{h})$ & Saving $(\$ / \mathrm{h})$ \\
\hline $00: 00$ & 277 & $13,676.616$ & $13,681.591$ & -4.975 \\
$01: 00$ & 269 & $13,348.237$ & $13,351.469$ & -3.232 \\
$02: 00$ & 267 & $13,265.617$ & $13,268.94$ & -3.323 \\
$03: 00$ & 274 & $13,555.347$ & $13,557.797$ & -2.450 \\
$04: 00$ & 277 & $13,679.997$ & $13,681.591$ & -1.594 \\
$05: 00$ & 276 & $13,638.415$ & $13,640.328$ & -1.913 \\
$06: 00$ & 276 & $13,641.928$ & $13,640.328$ & 1.600 \\
$07: 00$ & 275 & $13,604.055$ & $13,599.061$ & 4.994 \\
$08: 00$ & 277 & $13,687.059$ & $13,681.591$ & 5.468 \\
$09: 00$ & 278 & $13,732.258$ & $13,722.857$ & 9.401 \\
$10: 00$ & 264 & $13,105.660$ & $13,145.145$ & -39.485
\end{tabular}




\begin{tabular}{ccccc}
$11: 00$ & 274 & $13,555.347$ & $13,557.797$ & -2.450 \\
$12: 00$ & 267 & $13,244.911$ & $13,268.94$ & -24.029 \\
$13: 00$ & 266 & $13,206.690$ & $13,227.675$ & -20.985 \\
$14: 00$ & 265 & $13,155.805$ & $13,186.409$ & -30.604 \\
$15: 00$ & 263 & $13,066.971$ & $13,103.879$ & -36.908 \\
$16: 00$ & 270 & $13,375.775$ & $13,392.736$ & -16.961 \\
$17: 00$ & 272 & $13,462.084$ & $13,475.267$ & -13.183 \\
$18: 00$ & 270 & $13,379.080$ & $13,392.736$ & -13.656 \\
$19: 00$ & 269 & $13,334.289$ & $13,351.469$ & -17.180 \\
$20: 00$ & 265 & $13,158.870$ & $13,186.409$ & -27.539 \\
$21: 00$ & 264 & $13,117.448$ & $13,145.145$ & -27.697 \\
$22: 00$ & 265 & $13,158.870$ & $13,186.409$ & -27.539 \\
$23: 00$ & 269 & $13,331.052$ & $13,351.469$ & -20.417 \\
Total & 6489 & $321,482.381$ & $321,797.038$ & -314.657 \\
Average & 270.375 & $13,395.099$ & $13,408.209$ & -13.111 \\
\hline
\end{tabular}

The following is a graphic image of the comparison of the input cost of fuel $(\$ / \mathrm{h})$ and the output of power produced by the generator (MW).

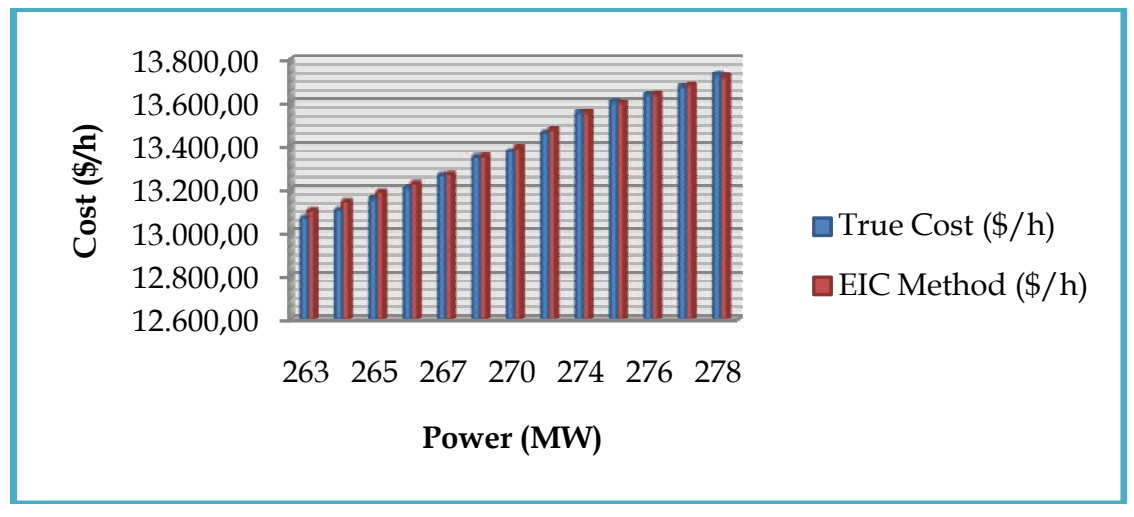

Figure 3. Graph of comparison of fuel costs and generation load before and after optimization

Figure 3 above is a graph of the comparison of the input fuel costs $(\$ / \mathrm{h})$ and the power output generated by the generator (MW) between the actual costs in the field. This figure shows that the fuel costs from the optimization using the Equal Incremental cost method are greater than the actual costs incurred by generators in the field. Comparison of fuel costs $(\$ / \mathrm{h})$ between actual costs in the field and optimization costs using the Equal Incremental cost method for more details, can be seen in the following Figure 4.

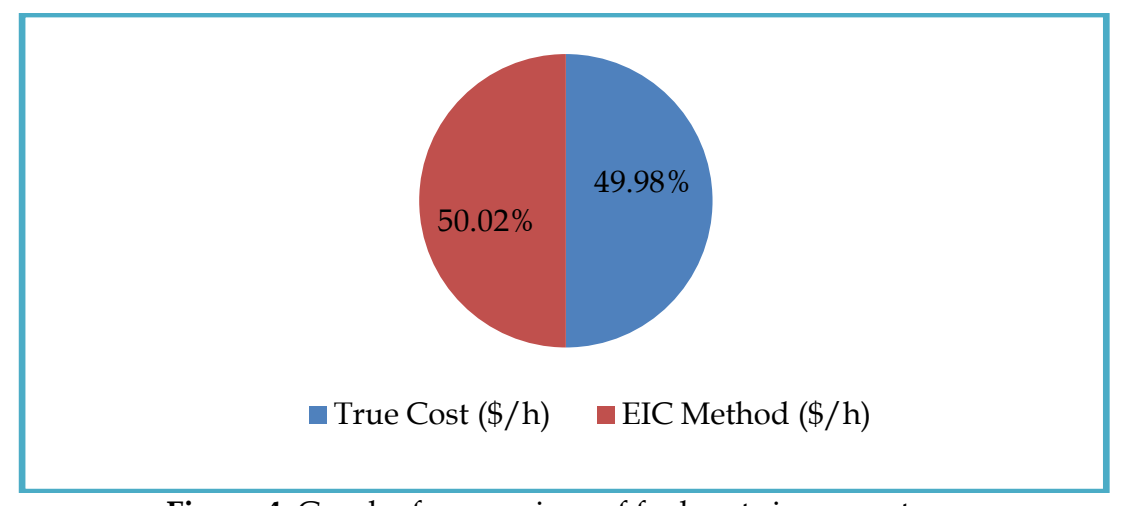

Figure 4. Graph of comparison of fuel costs in percent

The percentage of this fuel cost is obtained from the quotient between the total cost of the incremental cost method and the actual cost in the field with the total cost of the incremental cost method and the actual cost in the field and then multiplied by $100 \%$. The savings obtained using the Equal Incremental Cost method is $-0.033 \%(\$ / \mathrm{h})$. This minus value is obtained from the reduction in actual fuel costs in the field, which is cheaper than the optimization result of the Equal Incremental Cost method. 


\section{Conclusions}

From the results of the analysis and discussion carried out, the following conclusions can be drawn:

1. The equation for the input output characteristics of PLTU Pangkalan Susu with the Linear Regression equation approach at generator unit 1 , namely $\frac{d F_{1}}{d P_{1}}=42.5 P_{1}+1,052.1$ and on generating units 2 , namely $\frac{d F_{2}}{d P_{2}}=40.1 P_{2}+1,194.9$

2. The results of calculations using the Equal Incremental Cost method with the Linear Regression approach when the maximum load is $278 \mathrm{MW}$ is $13,722.857 \$ / \mathrm{h}$ and when the minimum load is $263 \mathrm{MW}$ is $13,103.879 \$ / \mathrm{h}$.

3. The results of calculations using the Equal Incremental Cost method using the Linear Regression (Least Square) approach obtained a cost of $-0.033 \%$ or an average of $-13.111 \$ / \mathrm{h}$ when compared to the value of existence in the field.

4. The optimization calculation using the Equal Incremental Cost method with the Linear Regression approach is not feasible to be applied at PLTU Pangkalan Susu because the actual costs in the field are cheaper when compared to the results of optimization calculations.

\section{References}

Dewangan, S. K., Jain, A. and Huddar, A. P. (2015) ‘Comparison of Particle Swarm Optimization with Lambda Iteration Method to Solve the Economic Load Dispatch Problem', pp. 1900-1907.

Dike, D. O., Adinfono, M. I. and Ogu, G. (2013) ‘Economic Dispatch of Generated Power Using Modified LambdaIteration Method', 7(1), pp. 49-54.

Hakimah, Y. (2016) 'Penjadwalan Operasi Pembangkit Pltg Gunung Megang Berdasarkan Biaya Bahan Bakar', 4, pp. 3143.

Hasibuan, A. (no date) 'Menentukan pengoperasian ekonomis pada pembangkit listrik tenaga uap', (1), pp. 2-6.

Iskandar, I. (2016) 'Pembagian Beban Secara Ekonomis Pada Pembangkit Thermal Menggunakan Cuckoo Optimization Algorithm', pp. 507-514.

Kristianto, D., Suyono, H. and Wijono (2014) 'Operasi Ekonomis Pembangkit Tenaga Listrik dengan Metode Iterasi Lambda Meggunakan Komputasi Paralel', student jurnal UB, pp. 1-6.

Mariang, Y. (no date) 'Optimalisasi Penjadwalan Pembangkit Listrik di Sistem Sorong', pp. 2-7.

Marsudi, D. (2006) Operasi Sistem Tenaga Listrik. Pertama. Yogyakarta.

Nabila, H. (2017) Analisis Economic Dispatch Pada Pltu Sektor Bukit Asam Menggunakan Metode Iterasi Lambda Dan Dynamic Programming, skripsi.

Pertiwi, N. P., Syahrizal and Siregar, R. H. (2018) 'Analisa Economic Dispatch Pada Unit Pembangkit Menggunakan Metode Iterasi Lambda Berdasarkan Base Point And Participation Factors', 3(2), pp. 24-29.

Pramudia, D., Hardiansyah and Junaidi (no date) ‘Penyelesaian Economic Dispatch Pada Unit Unit Pembangkit Thermal Dengan Menggunakan Artificial Bee Colony (Abc) Algorithm’.

Rusilawati, Penangsang, O. and Soeprijanto, A. (no date) 'Implementasi Metoda Taguchi Untuk Economic Dispatch Pada Sistem IEEE 26 BUS', pp. 1-9.

Suman, M. et al. (2016) 'Solution of Economic Load Dispatch problem in Power System using Lambda Iteration and Back Propagation Neural Network Methods', 8(2), pp. 347-355. doi: 10.15676/ijeei.2016.8.2.8.

Syafii and Monice (no date) 'Operasi Ekonomis (Economic Dispatch) Pembangkit Listrik Tenaga Sampah (PLTSa) dan (PLTG) Dalam Melayani Beban Puncak', pp. 35-39.

Syah, K. et al. (2012) 'Analisis Perbandingan Economic Dispatch Pembangkit Menggunakan Metode Lagrange dan CFPSO', Jurnal EECCIS, 6(1), pp. 91-96.

Takeang, C. and Aurasopon, A. (2019) 'Multiple of Hybrid Lambda Iteration and Simulated Annealing Algorithm to Solve Economic Dispatch Problem with Ramp Rate Limit and Prohibited Operating Zones', Journal of Electrical Engineering \& Technology. Springer Singapore, 14(1), pp. 111-120. doi: 10.1007/s42835-018-00001-z.

Wood, A. J. and Wollenberg, B. F. (1996) Power generation Operation and Control. Third Edit. Jhon Wiley \& Sons, Inc.

Yuliara, I. M. (2016) 'Regresi Linier Sederhana', Fisika, pp. 7-41. 